\title{
Institutional System of Human Development and Institutional Environment: Relationship Features
}

\author{
Olena Stryzhak ${ }^{1^{*}}$ \\ ${ }^{1}$ Simon Kuznets Kharkiv National University of Economics, Tourism Department, 9-A, Nauky Ave., \\ Kharkiv, 61166, Ukraine
}

\begin{abstract}
The article considers the features of human development in the context of the concept of sustainable development. The need to study the institutional system of human development as regulated multilevel system of interconnected formal and informal institutions is justified. The relationship between the level of human development and the quality of the institutional environment is determined using the methods of correlation analysis. Analyse covers 214 countries and territories for 2017. The results of the correlation analysis show that there is a strong direct interconnection between HDI and WGI. The correlation ranges from significant to very strong one. This gives grounds for conclusion that there is influence of the quality of institutional environment on the level of human development.
\end{abstract}

\section{Introduction}

In modern conditions of the overpopulation of the planet, exhaustion of natural resources, global warming, the attention of scientists and public figures is attracted not only to the problems of achieving economic prosperity and ensuring the rates of economic growth, but also the problems of implementing the economic interests of society together with the development of other spheres, including social, political, moral, cultural, ethical, ecological and other aspects of development. In 1987, the Bruntland Commission in its report defined sustainable development as "development that meets the needs of the present without compromising the ability of future generations to meet their own needs" [5]. The implementation of the ideas of the sustainable development concept directs the state to the organic development of all sectors of society, focusing on the long-term perspective and creating a growth potential for future generations.

The human development is an important component and one of the prerequisites for sustainable development. UN Development Program defines human development as a process of enlarging people's choices. But human development is also the objective, so it is both a process and an outcome. Human development implies that people must influence the processes that shape their lives. In all this, economic growth is an important means to human development, but not the end. Human development is the development of the people

\footnotetext{
* Corresponding author: sssselllennnn@gmail.com
} 
through building human capabilities, by the people through active participation in the processes that shape their lives and for the people by improving their lives. It is broader than other approaches, such as the human resource approach; the basic needs approach and the human welfare approach [3, p. 2]. The implementation of the main principles embodied in the concept of human development allows us to create conditions for the full development of a person, observance of their rights, providing opportunities for a long, healthy, full life in harmony with nature and society.

It should be noted that the economic component is rather important, but not the only condition for ensuring effective human development. It is also important to determine how income is distributed in society, what needs it is directed at, what the distribution inequality is, and so on. Accordingly, in formation of human development opportunities, priority is given not only to economic but also to its institutional support, that is, how the institutions, that provide human development, are organized, what their qualitative composition is, how they are combined within a single system. From these positions, the institutional system of human development is a regulated multilevel system of interconnected formal and informal institutions directed at ensuring the conditions of human development.

Both formal and informal institutions are important for insuring human development opportunities. And if the formal ones can be established by a directive, by adopting one or another law or by-law, then informal ones are evolving in a society in evolutionary way, and therefore are more complex for regulation, management and change. For example, the institution of remuneration of labour includes both a formal institution of minimum subsistence level, which is established by law, and informal one - the market rate of wages by spheres and sectors of economy.

\section{Research methodology}

The level of human development is assessed by the appropriate Human Development Index (HDI). The methodology of calculating the index includes the following indicators: Life expectancy at birth; Expected years of schooling; Mean years of schooling; Gross national income (GNI) per capita.

The state of the institutional environment in the country can be assessed on the basis of Worldwide Governance Indicators (WGI, which is calculated by the World Bank according to the methodology of D. Kaufmann, A. Kraay, M. Mastruzzi [1, p. 4].

The indicators cover three areas of management and include six aspects:

(a) The process by which governments are selected, monitored, and replaced:

1. Voice and Accountability (VA);

2. Political Stability and Absence of Violence/Terrorism (PV);

(b) The capacity of the government to effectively formulate and implement sound policies:

3. Government Effectiveness (GE);

4. Regulatory Quality (RQ);

(c) The respect of citizens and the state for the institutions that govern economic and social interactions among them:

5. Rule of Law (RL);

6. Control of Corruption (CC).

The indicators take values in the range from -2.5 to 2.5 , where the bigger value of the indicator reflects the more effective management. Accordingly, the percentage value among all countries is determined, ranging from the lowest (0) to the highest (100) rank. The indicators are based on several hundred individual variables of the perception of management, received from 35 separate data sources from 33 different organizations from 
around the world. They cover 214 countries and territories for 1996, 1998, 2000, and annually for 2002-2018.

In order to assess the relationship between the level of human development and the quality of institutional environment, the study used the methods of correlation analysis.

The Pearson correlation coefficient was used in this research since the analyzed parameters are measured in the rank scales (scales of order). However, as the Pearson correlation coefficient is predominantly intended for use in metric spaces of indicators, the Spearman and Tau Kendall rank correlation was also used in the analysis, which is specially designed for the objects of non-numeric statistics. The Spearman rank correlation coefficient more accurately takes into account the quantitative degree of correlation between the variables and is a nonparametric analogue of the classical Pearson correlation coefficient, but when it is calculated, the ranks are taken into account and not the indicators of comparable variables (arithmetic mean and dispersion) related to the distribution. Unlike the Spearman coefficient, Tau Kendall analyzes the interrelations between variables in more detail, sorting all possible matches between pairs of values of variables.

This study makes calculations using the software Statistica. Obtaining unambiguous results with the use of all these coefficients of correlation provides grounds for recognition of the obtained findings as objective ones.

\section{Research findings}

The institutional system of human development consists of basic and derivative institutions, which can be both formal and informal.

The basic institutions of human development include:

- institution of education (pre-school, school, higher, industrial, self-study, advanced training, retraining);

- health care institution (state, private, insurance, non-traditional medicine, selfmedication, etc.);

- social security institution (social transfers, compensations, subsidies, benefits, established minimum subsistence level ;

- labor pay institution (minimum wage, fair remuneration for labor, market rate of wages, labor legislation);

- institution of protection of human rights and freedoms (guaranteeing the right to work, religion, education, freedom of speech, distribution of income from labor participation in the production process, etc.).

The derivative institutions are created on the basis of basic institutions, which complement them and ensure the sustainability of functioning of the institutional system of human development.

The institutional system of human development is part of the institutional environment of the country. The assessment of the relationship between the quality of the institutional environment and the level of human development can be obtained by identifying a correlation between these indicators. The Pearson (product-moment) correlation, the Spearman rank correlation, and Kendall's Tau correlation are most often used to identify correlation dependence. The calculations of the coefficients were made on the basis of a sample for 187 countries and territories for 2017, for which data were available by all the indicators under analysis.

The relationship between HDI and WGI is presented in Table 1. 
Table 1. The relationship between HDI and WGI

\begin{tabular}{|l|c|c|c|}
\hline \multirow{2}{*}{ Variable } & \multicolumn{3}{|c|}{$\begin{array}{l}\text { Marked correlations are significant at } \mathrm{p}<, 05000 \\
\mathrm{~N}=187 \text { (Casewise deletion of missing data) }\end{array}$} \\
\cline { 2 - 4 } & $\begin{array}{c}\text { Pearson } \\
\text { Correlations }\end{array}$ & $\begin{array}{c}\text { Spearman Rank } \\
\text { Order Correlations }\end{array}$ & $\begin{array}{c}\text { Kendall Tau } \\
\text { Correlations }\end{array}$ \\
\hline VA & 0.591586 & 0.597818 & 0.431848 \\
\hline PS & 0.628240 & 0.632721 & 0.454088 \\
\hline GE & 0.854106 & 0.869506 & 0.692737 \\
\hline RQ & 0.805191 & 0.827067 & 0.650074 \\
\hline RL & 0.770315 & 0.788669 & 0.603344 \\
\hline CC & 0.715771 & 0.734156 & 0.548212 \\
\hline
\end{tabular}

The results of the correlation analysis show that there is a strong direct interconnection between HDI and WGI. The correlation ranges from significant to very strong one. This gives grounds for conclusion that there is influence of the institutional environment on the level of human development. In this case, the highest positive interdependence is observed between HDI and GE and RQ. This confirms the necessity for direct state institutional regulation of human development, especially in the direction of supporting institutions of education and health care and ensuring an adequate level of funding.

Graphical representation of the correlation relationship between indicators of HDI and WGI is presented in Fig. 1.

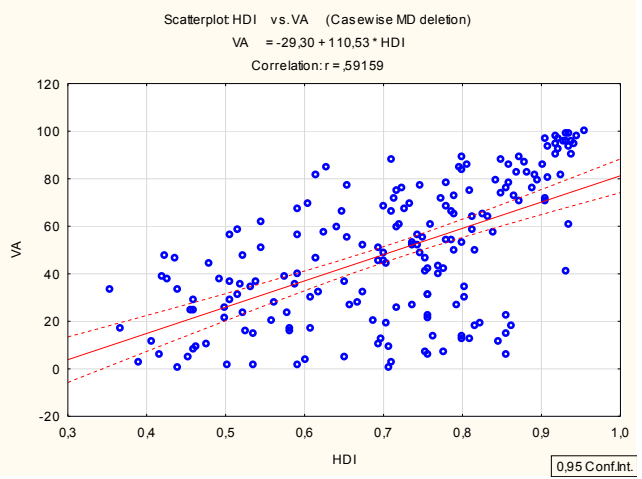

The relationship between HDI and VA Scatterplot:HDI vs.PS (Cas ewise MD deletion) PS $=-34,33+114,96 * \mathrm{HDI}$

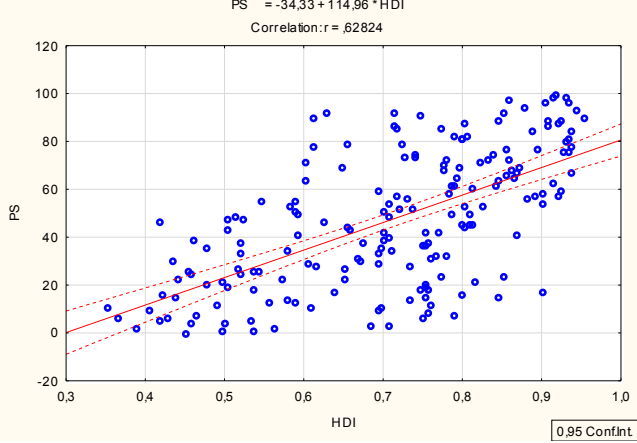

The relationship between HDI and PS

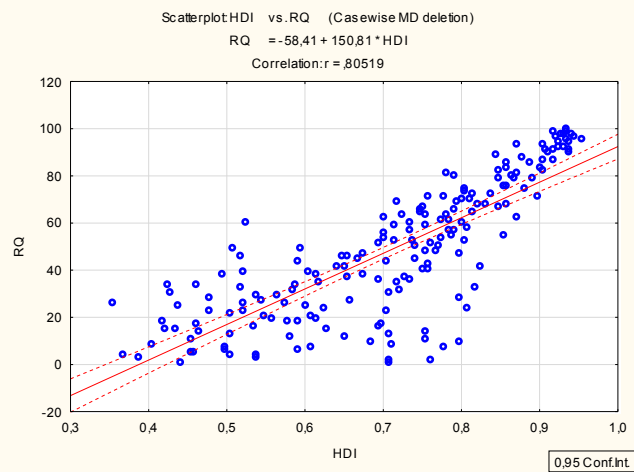

The relationship between HDI and RQ $\begin{array}{ccc}\text { Scatterplot: } \mathrm{HDI} & \text { vs. RL (Casewise MD deletion) } \\ \mathrm{RL} & =-54,03+144,01^{*} \mathrm{HDI}\end{array}$

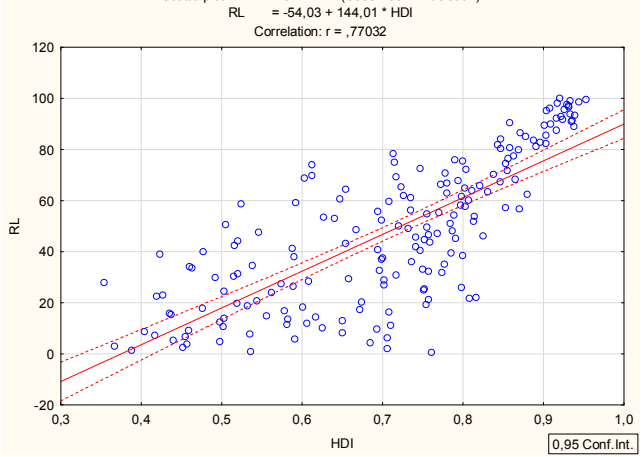

The relationship between HDI and RL 


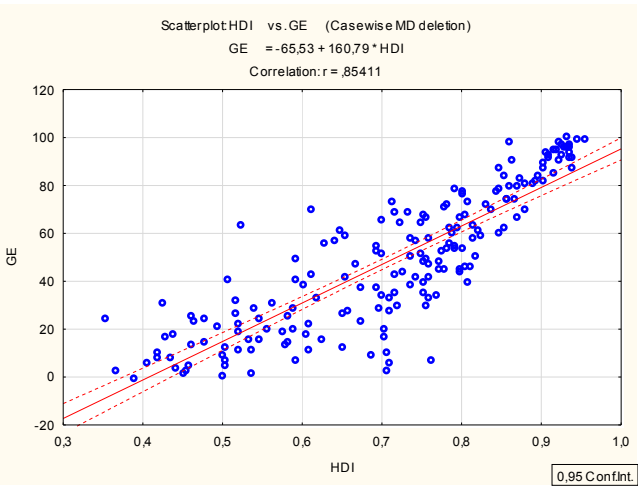

The relationship between HDI and GE

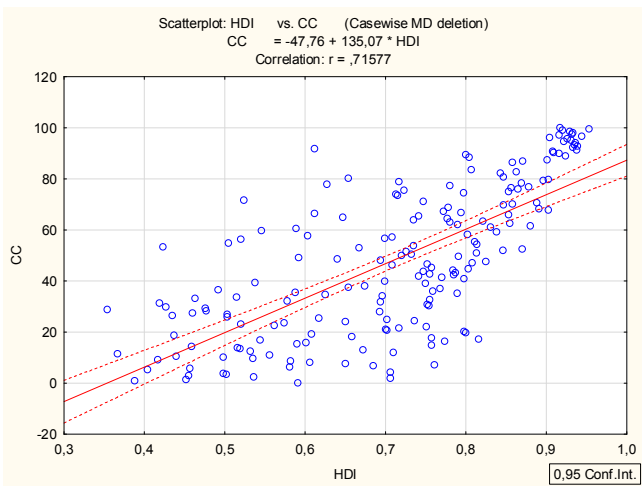

The relationship between HDI and CC

Fig. 1. The relationship between HDI and WGI

Based on the results of the calculations, the following conclusions can be drawn. First, the level of human development depends on the quality of institutional environment. Correlation dependence is observed between all the analyzed variables. However, the relationship between HDI and WGI is different for different aspects of management and varies from average to very strong. Secondly, as it can be seen from the graphical interpretation of the research results, there is an uneven spread of the values of the analyzed indicators. Thus, the scatter of RQ and GE indicators in relation to HDI is much less than when determining the level of HDI connection with other indicators.

Hence, the effectiveness of the institutional system of human development can be ensured under conditions of the presence of a favorable institutional environment. The unfavorable institutional environment with the state's support of ineffective formal institutions or the absence of appropriate sanctions for their removal can lead to deformations of the institutional system and the widespread use of destructive informal institutions (corruption, bribery, nepotism, etc.) to destabilize the institutional system and slow down development processes. For example, a significant increase in wages by the state in certain sectors of economy leads to an imbalance in the labor market, and a corresponding drop in demand for educational services for the training of professionals in those specialties that are paid lower. The increase of tax pressure, the lack of effective control and sanctions on the part of the state in relation to economic entities generates more serious problems for the national economy, starting from shadow employment, hiding of income, the transfer of the part of economic activity "to the shadow" and financial resources to other countries or offshore zones, ending with "brain drain" and growth of criminal activity.

In our view, state regulation of all aspects of development, including human, must be expressed not only in the provision of a sufficient number of formal regulatory institutions, but also in the creation of conditions for the effective use of informal institutions, which, together with the formal ones, form an institutional system. As K. Charakhchyan rightly notes, the problem is that an increase in the number of formal institutions does not automatically lead to positive changes in the institutional environment of the business entities. Moreover, a set of simulacrum institutions (dummy institutions), which drive out really useful and effective institutions for firms and households, can be formed [6, p. 69]. Thus, for the implementation of the basic principles and ideas of human development as a component of the concept of sustainable development, the construction of an effective institutional system, the formal and informal institutions of which complement each other, is of great importance. 


\section{Conclusions}

The contradictions between formal and informal norms can lead to an imbalance in the institutional system of human development, hampering its development, or even blocking its functioning. Consequently, the harmonization of the formal rules that are introduced, with those informal institutions that have been in society for many years, that are generally recognized and are often more consistent and effective than the new formal ones, should take place. The rejection of the latter may lead to an institutional conflict, which may negatively affect the activities of some spheres of society and sectors of the national economy, as well as the economic system as a whole. Therefore, the realization, formation and adoption of such formal norms, which together with the existing informal ones will increase the efficiency of the functioning of institutional system, is an important task of the state. An ineffective formal institution, introduced from outside, may subsequently stimulate the emergence of a simulacrum institution - an institution that, formally existing and occupying its place in the institutional hierarchy of society, in reality is only a visibility, an "empty form", the presence of which conceals the fact of its real absence. In the general sense, the simulacrum is a representation (a copy) of an object whose original does not exist in reality, which occupies the place of this object and is subsequently perceived by others as the primary object. This is a copy that does not have the original and which replaces the really existing objects and relationships.

The practice of state support of inefficient formal institutions leads to incorporation of simulacrum institutions, which subsequently oppose to the introduction of more effective institutions, into the institutional system. Since the simulacrum institutions are closely interconnected, they either "intertwine" with the existing institutional system or form their alternative, in parallel acting simulacrum institutional system. Research and assessment of the impact of simulacrum institutions on functioning of the institutional system as a whole, and the human development system, in particular, is, in our opinion, a promising direction for further research.

\section{References}

1. D. Kaufmann, A. Kraay, M. Mastruzzi, The Worldwide Governance Indicators: Methodology and Analytical Issues. World Bank Policy Research Working Paper No. 5430. Available at SSRN: https://ssrn.com/abstract=1682130 (2010).

2. Human Development Indices and Indicators: 2018 Statistical update. [Electronic resource]. URL: http://hdr.undp.org/en/2018-update

3. Human Development Report 2016: Human Development for Everyone, Publisher: United Nations. - 286 p. [Electronic resource]. URL: http://hdr.undp.org/sites/default/files/2016_human_development_report.pdf

4. The Worldwide Governance Indicators. [Electronic resource]. URL: https://info.worldbank.org/governance/wgi/

5. United Nations General Assembly. Report of the world commission on environment and development: Our common future. Oslo, Norway: United Nations General Assembly, Development and International Co-operation: Environment. (1987).

6. К. Чарахчян, Перспективы трансформации институцииональной политики государства. Научные труды ДонНТУ. Серия: экономическая. Выпуск 38-1, C. 69-73. (2010). 